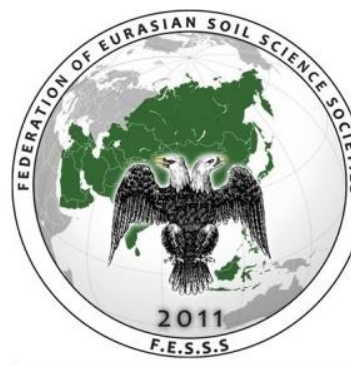

Eurasian Journal of Soil Science

Journal homepage : http://ejss.fesss.org

\title{
Partitioning of heavy metals in different particle-size fractions of soils from former mining and smelting locations in Austria
}

\author{
Anto Jelecevic a,*, Manfred Sager b, Daniel Vollprecht c, \\ Markus Puschenreiter a , Peter Liebhard a \\ a University of Natural Resources and Life Sciences Vienna, Vienna, Austria \\ b Bio Forschung Austria, Vienna, Austria \\ c Montanuniversität, Leoben, Austria
}

\begin{abstract}
Austrian soils from mainly historical mining and smelting sites were separated into four particle size fractions (coarse sand, fine sand, silt and clay) to distinguish the possible origins and pathways of heavy metals. Each fraction was extracted with aqua regia to determine the pseudo-total content and with $\mathrm{CaCl}_{2}$ to determine the available content of metals. The soil mineralogical composition of the $<2000 \mu \mathrm{m}$ fraction was determined by X-ray diffraction (XRD). In general, the concentration of heavy metals and metalloids increased as soil particle size decreased. Based on the correlations of concentrations vs. the log of the mean particle size, obtained from each fraction the presence of unweathered allochthonous minerals were especially present in samples from locations at Rabenstein for most trace elements, at Arzwaldgraben for $\mathrm{Cd}, \mathrm{Co}, \mathrm{Mn}$ and $\mathrm{Pb}$, at Johnsbach for $\mathrm{Cd}, \mathrm{Co}, \mathrm{Mn}, \mathrm{Pb}$ and $\mathrm{Zn}$ and at Pilgersdorf for $\mathrm{Cr}$. The opposite trend was found for the samples of the industrial area of Arnoldstein, Zeltweg and Hinterlobming suggesting that their metal load was derived from the discharge of effluents or from weathered phases.
\end{abstract}

Keywords: Heavy metals, minerals, soil particle size fractions, separation.

(c) 2021 Federation of Eurasian Soil Science Societies. All rights reserved

\section{Introduction}

Heavy metals in soils pose a major challenge for humanity due to their toxic effects on living things. They can occur in soil in various forms; dissolved in soil solution, adsorbed to organic and inorganic soil exchangers, trapped in mineral constituents, precipitated in conjunction with other soil constituents, incorporated into living soil organisms (Adriano, 1986; Bradl, 2004).

The size of soil particles is one of the main parameters which play an important role in mobility and bioavailability of heavy metals. Finer soil particles or soil colloids (with a diameter less than $2 \mu \mathrm{m}$ ) have the ability to accumulate higher concentrations of heavy metals due to the high content of secondary minerals like clay minerals, Fe/Mn/Al oxides and hydroxides, and carbonates and organic matter, which can efficiently adsorb heavy metals due to their high specific surface areas (Mandzhieva et al., 2014; Yao et al., 2015). The inorganic colloids can adsorb heavy metals via coprecipitation, adsorption, surface complex formation, ion exchange and penetration of the crystal lattice (Chao and Theobald, 1976). Organic matter possesses high affinity for heavy metals, resulting from complexation of various functional groups $(-\mathrm{OH}$, - $\mathrm{COOH}$, etc.) (Bradl, 2004). The silt fraction $(2-63 \mu \mathrm{m})$ mainly contains secondary mineral phases, like clay minerals, iron and aluminum oxides, allophanes, mono- and polysilicic acids, and organic and organomineral compounds. Sand particles with a diameter higher than $63 \mu \mathrm{m}$ are largely composed of quartz (predominantly) feldspars and heavy minerals like amphiboles (Mandzhieva et al., 2014). The sand fraction

\footnotetext{
* A. Jelecevic

M. Sager

D. Vollprecht

M. Puschenreiter

P. Liebhard

anto.jelecevic@students.boku.ac.at m.sager@bioforschung.at Daniel.Vollprecht@unileoben.ac.at markus.puschenreiter@boku.ac.at peter.liebhard@boku.ac.at
}

0000-0002-5246-9535 (Corresponding author)

0000-0003-3513-866X

0000-0003-1809-5223

0000-0002-7298-4163

0000-0001-9971-6743 
is a weak adsorbent for heavy metals as its specific surface area is much lower. In general, metal inputs transported via soil solution are adsorbed at fine soil particles (Zhang et al., 2013; Gong et al., 2014), while the contents of metals from mineral abrasion show no clear dependence from soil particle size (Sager and Belocky, 1990; Ajmone-Marsan et al., 2008). In case of chemical weathering the concentrations of trace elements are thus linear versus the negative logarithm of the mean grain size diameter (Sager and Belocky, 1990). This is not the case, however, if trace elements are present in lower soluble minerals, or if transportation effects in rivers change the skewness of this distribution. In adjacent soils, metals from geogenic sources, are usually present in smaller amounts than in the corresponding ores. In general, the solubility of metals is determined by their incorporation into minerals or adsorption at their surfaces (Adriano, 1986).

Soils in the vicinity of mining and smelting industries contain metal-bearing deposited particulates. Whereas heavy minerals in the mine tailing samples investigated, made $4 \%$ of the fraction $<2 \mathrm{~mm}$, they contained $24 \%$ of the metal loads. Metal-bearing phases can be investigated in detail by automated scanning electron microscopy equipped with energy dispersion spectroscopy, to avoid bias in searching and identifying metal bearing phases. Pre-selected sample areas can be further imaged by use of an electron probe micro-analyzer. In mining and smelting areas, the majority of contaminations is generally concentrated in the topsoil layer. Geogenic particles originate from the geological environment or from mechanical processing of the ore, like pyrite $\mathrm{FeS}_{2}$, chalcopyrite $\mathrm{CuFeS}_{2}$, or enargite $\mathrm{Cu}_{3} \mathrm{AsS}_{4}$. The sulphides usually exhibit well-developed alteration rims composed of metal-bearing Fe-oxides (Tuhý et al., 2020). Mine tailings present an important source of heavy metals like $\mathrm{Cu}, \mathrm{Pb}, \mathrm{Zn}, \mathrm{Cd}, \mathrm{Cr}$ and As (Chung et al., 2005, Lim et al., 2008). Under acid conditions, heavy metals become mobile and are easily leached out of the tailing deposits ("Acid mine drainage") (Pandey et al., 2007). In mine tailings from a historic zinc-mine within freely draining cambisols, in the clay fraction $(<2 \mu \mathrm{m})$ mainly quartz, mica and kaolinite were identified by X-ray diffraction. Heavier density fractions were separated by tetrabromoethane (density $>2.7 \mathrm{~g} / \mathrm{cm}^{3}$ ) and further by diodomethane (density $>3.3 \mathrm{~g} / \mathrm{cm}^{3}$ ), which contained goethite, hematite, rutile, and barite as main minerals, as well as the metalliferous minerals smithsonite $\left(\mathrm{ZnCO}_{3}\right)$ and leadhillite $\left(\mathrm{Pb}_{4} \mathrm{SO}_{4}\left(\mathrm{CO}_{3}\right)_{2}(\mathrm{OH})_{2}\right)$ as weathering products. Smithsonite and barite tended to increase in coarser fractions, whereas leadhillite and rutile were enhanced in fine size fractions. No crystalline phases were found for $\mathrm{Cu}$ and $\mathrm{Cd}$ because they were associated with organics or other minerals (Mattigod et al., 1986).

In Austria due to construction works, large amounts of excavated soils and subsoils do not meet the requirements for recycling (due to exceeding of permitted values for heavy metals) and have to be landfilled (Jelecevic et al., 2018, 2019). Although the Federal Management Waste allows in some cases higher values for geogenic heavy metals this generalized expert opinion does not provide a method how the possible origin of heavy metals can be determined. It is therefore assumed that a certain amount of excavated material is not adequately classified and is disposed of in landfills (Jelecevic et al., 2018). The aim of this work, was to separate four particle size fractions; coarse sand/2000-200 $\mu \mathrm{m}$, fine sand/200-63 $\mu \mathrm{m}$, silt/63-2 $\mu \mathrm{m}$ and clay $/<2 \mu \mathrm{m}$ from soils mainly at historical mining and smelting sites in Austria and to determine the total and available content of these fractions which should help to distinguish the possible origins and the toxic potential of each metal.

\section{Material and Methods}

\section{Materials}

In this study eight soil samples (seven with high metal levels) were investigated (Figure 1). The Styrian soils; Arzwaldgraben (Arz), Johnsbach (Joh) and Rabenstein (Rab) are from former mining and mineral processing sites while the others (Hinterlombing (Hin), Kraubath (Kra) and Zeltweg (Zel)) are grassland soils without known information about their industrial use in the past. The soil samples Arnoldstein - A(C) from Carinthia and Pilgersdorf - P (C) from Burgenland were used as control soils for an anthorpogenic respectively geogenic metal contamination. The samples were taken with a geological drill (so called "Pürckhauer") and the upper $25 \mathrm{~cm}$ were used for subsequent studies. The main characteristics of the sampled soils are presented in Table 1.

\section{Methods}

\section{$\mathrm{X}$-ray diffraction}

The mineralogical compositions of the samples were determined by X-ray diffraction (XRD) at the Graz University of Technology (Panalytical XPert Pro, step size $0.001^{\circ} 2$ Theta, K $\alpha=1.78901 \AA$ A, $409 \mathrm{~mA}, 40 \mathrm{kV}$ ). Rietveld refinement for phase quantification was conducted using the automated mode, which includes refinement of the scale factors, the background, the zero shift, the lattice parameters, and the peak shape parameter W. 


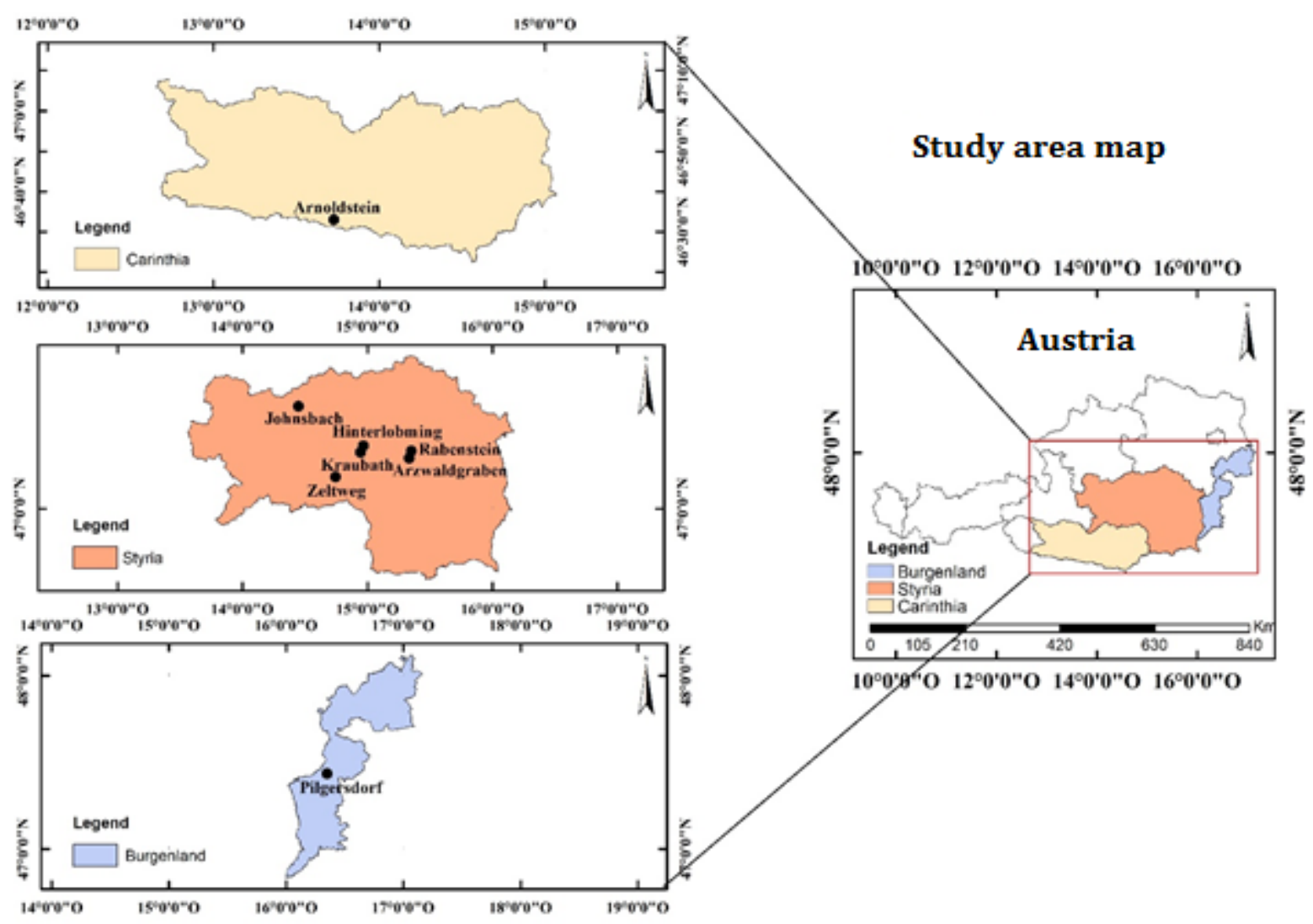

Figure 1. Sampling map of the selected area

Table 1. List of soil samples used in this study with their characteristics

\begin{tabular}{|c|c|c|c|c|c|c|c|c|}
\hline Sample & $\begin{array}{l}\text { Region and } \\
\text { Geographic } \\
\text { coordinates }\end{array}$ & Present Use & Past Use & Substrate & Soil type & $\begin{array}{l}\text { Soil } \\
\text { texture }\end{array}$ & pH & $\begin{array}{c}\text { Total } \\
\text { Organic } \\
\text { Carbon } \\
\end{array}$ \\
\hline $\begin{array}{l}\text { Arz } \\
\text { (Jelecevic et al., 2019) }\end{array}$ & $\begin{array}{l}\text { Styria } \\
47^{\circ} 14.261^{\prime} \mathrm{N} \\
15^{\circ} 16.798^{\prime} \mathrm{E}\end{array}$ & Grassland & $\begin{array}{l}\mathrm{Pb}-\mathrm{Zn} \\
\text { mining }\end{array}$ & Alluvial fan & Gley & $\begin{array}{l}\text { Silty } \\
\text { loam }\end{array}$ & 7.4 & $5.4 \%$ \\
\hline Hin & $\begin{array}{l}\text { Styria } \\
47^{\circ} 17.556^{\prime} \mathrm{N} \\
15^{\circ} 02.300^{\prime} \mathrm{E}\end{array}$ & Grassland & none & Alluvial fan & $\begin{array}{l}\text { Alluvial } \\
\text { soil }\end{array}$ & $\begin{array}{l}\text { Sandy } \\
\text { loam }\end{array}$ & 6.8 & $3.7 \%$ \\
\hline $\begin{array}{l}\text { Joh } \\
\text { (Jelecevic et al., 2019) }\end{array}$ & $\begin{array}{l}\text { Styria } \\
47^{\circ} 31.723^{\prime} \mathrm{N} \\
14^{\circ} 36.857^{\prime} \mathrm{E}\end{array}$ & Grassland & $\begin{array}{l}\mathrm{Cu}-\mathrm{As} \\
\text { mining }\end{array}$ & Alluvial fan & Gley & $\begin{array}{l}\text { Sandy } \\
\text { loam }\end{array}$ & 5.9 & $14 \%$ \\
\hline $\begin{array}{l}\text { Kra } \\
\text { (Jelecevic et al., 2019) }\end{array}$ & $\begin{array}{l}\text { Styria } \\
47^{\circ} 18.034^{\prime} \mathrm{N} \\
14^{\circ} 55.955^{\prime} \mathrm{E}\end{array}$ & $\begin{array}{l}\text { Grassland and } \\
\text { farmland in } \\
\text { crop rotation }\end{array}$ & none & Mica shist & Cambisol & Loam & 7.3 & $4.6 \%$ \\
\hline $\begin{array}{l}\text { Rab } \\
\text { (Jelecevic et al., 2019) }\end{array}$ & $\begin{array}{l}\text { Styria } \\
47^{\circ} 15.023^{\prime} \mathrm{N} \\
15^{\circ} 18.450^{\prime} \mathrm{E}\end{array}$ & Grassland & $\begin{array}{c}\mathrm{Pb}-\mathrm{Zn} \\
\text { mining and } \\
\text { processing }\end{array}$ & Phyllite & Cambisol & Loam & 6.9 & $2.8 \%$ \\
\hline $\begin{array}{l}\text { Zel } \\
\text { (Jelecevic et al., 2019) }\end{array}$ & $\begin{array}{l}\text { Styria } \\
47^{\circ} 11.575^{\prime} \mathrm{N} \\
14^{\circ} 43.325^{\prime} \mathrm{E}\end{array}$ & Grassland & Not known & Alluvial fan & Cambisol & $\begin{array}{l}\text { Silty } \\
\text { loam }\end{array}$ & 6.2 & $4.1 \%$ \\
\hline $\begin{array}{l}\text { A (C) } \\
\text { (Kuffner et al., 2008) }\end{array}$ & $\begin{array}{l}\text { Carinthia } \\
\text { Not given }\end{array}$ & Not known & $\begin{array}{c}\mathrm{Pb}-\mathrm{Zn} \\
\text { mining and } \\
\text { processing }\end{array}$ & Not known & Leptosol & $\begin{array}{l}\text { Silty } \\
\text { loam }\end{array}$ & 6.6 & $1.3 \% *$ \\
\hline $\begin{array}{l}\mathbf{P}(\mathbf{C})(\text { Redlschlag in } \\
\text { Wenzel et al., 2003)* }\end{array}$ & $\begin{array}{l}\text { Burgenland } \\
\text { Not given }\end{array}$ & $\begin{array}{l}\text { Serpentine } \\
\text { quarry }\end{array}$ & $\begin{array}{l}\text { Serpentine } \\
\text { quarry }\end{array}$ & Serpentine & Leptosol & $\begin{array}{l}\text { Silty } \\
\text { loam }\end{array}$ & 7.2 & $2.5 \% *$ \\
\hline
\end{tabular}

* In Kuffner et al. (2018) and Wenzel et al. (2003) described as Organic Carbon

\section{Soil partitioning}

The soil samples were passed through a $2-\mathrm{mm}$ sieve and then weighed into a $100 \mathrm{~mL}$ plastic beaker (about $30 \mathrm{~g}$ dry matter) and mixed with about $70 \mathrm{~mL}$ distilled water. The beaker was then placed on a lift table under the ultrasound probe. Thereafter the disaggregated soil suspension was passed through a $200 \mu \mathrm{m}$ and then through a $63 \mu \mathrm{m}$ sieve to separate the fractions $200 \mu \mathrm{m}-2 \mathrm{~mm}$ (coarse sand) and $63 \mu \mathrm{m}-200 \mu \mathrm{m}$ (fine 
sand). These fractions were thoroughly rinsed with deionized water, transferred into glass beakers and dried in the oven at $60^{\circ} \mathrm{C}$ to constant weight. Further separation of the fraction $<63 \mu \mathrm{m}$ was carried out by sedimentation in a centrifuge.

The sedimentation time of a given particle size in a rotating fluid over a given distance was calculated by the following formula:

$$
\mathrm{t}=\frac{63.0 * 10^{8} * \eta * \log \frac{\mathrm{R}}{\mathrm{S}}}{\mathrm{rpm}^{2} * \mathrm{~d}^{2} *\left(\mathrm{p}-\mathrm{p}_{\mathrm{fl}}\right)}
$$

$\mathrm{t}:$ centrifugation time [min]

$\eta \quad$ : Liquid viscosity [0.001 $\left.\mathrm{g} \mathrm{s}^{-1}\right]$

$\mathrm{R}$ : outer radius of the rotating fluid $[13.3 \mathrm{~cm}]$

$\mathrm{S}$ : Inner radius of the rotating fluid [9.3 $\mathrm{cm}]$ rpm : revolutions per minute 600

$\mathrm{d} \quad$ : analiscopic particle diameter $[2 \mu \mathrm{m}]$

$\rho$ : Density of the solid $\left[2.61 \mathrm{~g} \mathrm{~cm}^{-3}\right]$

$\rho_{\mathrm{fl}} \quad:$ density of liquid $\left[1 \mathrm{~g} \mathrm{~cm}^{-3}\right]$

According to the given equation, the sedimentation time of particles $<63 \mu \mathrm{m}$ was reached in $\mathrm{t}=4.22 \mathrm{~min}$. This was measured from the start time of the centrifuge until the beginning of the braking phase. If the acceleration phase of the centrifuge is taken into account, the optimal running time at $1000 \mathrm{rpm}$ is 2 minutes (Stemmer et al., 1998). After that the suspension containing the fraction $<63 \mu \mathrm{m}$ was transferred to four 250 $\mathrm{mL}$ centrifuge beakers, leveled to $10 \mathrm{~cm}$ level and tared to at least $0.1 \mathrm{~g}$ accuracy in a swing-bucket rotor in the centrifuge. After centrifugation at $600 \mathrm{rpm}$ for $4.22 \mathrm{~min}$, the cups were carefully removed from the rotor and the supernatant suspension (fraction $<2 \mu \mathrm{m}$ ) decanted into a $2 \mathrm{~L}$ beaker and put into an oven at $80^{\circ} \mathrm{C}$ and finally at $105^{\circ} \mathrm{C}$ until complete dryness. The residue $(63-2 \mu \mathrm{m})$ of the four cups was resuspended and transferred to a centrifuge cup. It was refilled to $\mathrm{cm}$ sinking distance and tared with a complementary cup. The suspension was well homogenized and centrifuged against the balance weight to the above conditions. This process for purifying the silt fraction was repeated a total 3 times. The now cleaned silt pellet was transferred to a beaker and dried in a drying oven at $105^{\circ} \mathrm{C}$ to constant weight.

All soil fractions were treated with aqua regia (for the determination of the pseudo-total metal content) and $\mathrm{CaCl}_{2}$ (for the determination of available metals) in a soil/solution ratio $1: 10 \mathrm{w} / \mathrm{v}$. After that the metal concentrations in all samples were analyzed with ICP-MS (Inductively coupled plasma mass spectrometry, Elan 9000 DRCe, Perkin Elmer). For each sample two digestions were made (3 g per $250 \mathrm{~mL}$ ). Two different dilutions of each digested samples were made to assure that the resulting concentrations were in the calibration range. Each of these samples was analyzed three times. The mean values of these three runs were calculated internally by the Elan software. The mean values of the runs of those solutions which were in the calibration range were used to calculate a new mean value. This is the value which is given in the results. The values of the dilutions which were not in the calibration range were discarded.

All experimental results including the mean values were analyzed by using Microsoft Excel 2013 and SigmaPlot 14.0. Correlations coefficient of mean particle size and heavy metal concentrations were performed to determine the statistical relationship of different soil fractions and the Grubbs test to identify the outliers from the selected locations.

\section{Results and Discussion}

The X-ray diffraction patterns of the investigated samples are displayed in Table 2. Most samples are mainly composed of quartz, muscovite and feldspars. Only the sample from Pilgersdorf is dominated by serpentine. Metal bearing phases could not be identified, except $\mathrm{PbO}$ at Zeltweg. This can be explained by the detection limit of XRD which is within the range of $2 \mathrm{wt} \%$.

Table 2. Mineralogical composition of selected soils in wt $\%$

\begin{tabular}{|c|c|c|c|c|c|c|c|c|}
\hline \multirow{2}{*}{ Mineral } & \multicolumn{8}{|c|}{ Soil (wt \%) } \\
\hline & Arz & Hin & Joh & Kra & $\mathrm{Rab}$ & Zel & $\mathrm{P}(\mathrm{C})$ & $A(C)$ \\
\hline Quartz, $\alpha-\mathrm{SiO}_{2}$ & 31 & 43 & 39 & 40 & 25 & 28 & 18 & 45 \\
\hline Muscovite, $\mathrm{KAl}_{2}\left(\mathrm{AlSi}_{3} \mathrm{O}_{10}\right)(\mathrm{OH})_{2}$ & 30 & 5 & 39 & 14 & 51 & 27 & $<1$ & 30 \\
\hline Albite, $\mathrm{NaAlSi}_{3} \mathrm{O}_{8}$ & 9 & 41 & 12 & 31 & 15 & 23 & - & - \\
\hline Anorthite, $\mathrm{CaAl}_{2} \mathrm{Si}_{2} \mathrm{O}_{8}$ & - & - & - & - & - & 1 & 7 & 12 \\
\hline Kalifeldspar, (Microcline), $\mathrm{KAlSi}_{3} \mathrm{O}_{8}$ & - & - & 1 & 9 & - & - & - & - \\
\hline Chlorite, $(\mathrm{Fe}, \mathrm{Mg}, \mathrm{Al})_{6}(\mathrm{Si}, \mathrm{Al})_{4} \mathrm{O}_{10}(\mathrm{OH})_{8}$ & 27 & 9 & 9 & 6 & 6 & 21 & 34 & 12 \\
\hline Rutile, $\alpha-\mathrm{TiO}_{2}$ & 2 & - & - & - & 4 & - & - & - \\
\hline Calcite, $\mathrm{CaCO}_{3}$ & 2 & - & - & - & - & - & - & - \\
\hline Litharge, $\mathrm{PbO}$ & - & - & - & - & - & 1 & - & - \\
\hline Serpentine $\mathrm{Mg}_{3}\left[\mathrm{Si}_{2} \mathrm{O}_{5}\left(\mathrm{OH}_{4}\right)\right]$ & - & - & - & - & - & - & 41 & - \\
\hline Dolomite $\mathrm{CaMg}\left(\mathrm{CO}_{3}\right)_{2}$ & - & 1 & - & - & - & - & - & 1 \\
\hline
\end{tabular}


Grubbs tests reveal that $\mathrm{Mn}$ is the only element which does not show outliers in individual particle size fractions. All elements show positive outliers within the particle size fractions. As and $\mathrm{Pb}$ distributions show several outliers in all particle size fractions above $2 \mu \mathrm{m}$. The number of outliers does not vary significantly between different particle size fractions (Table 3 ).

Table 3. Grubbs test, G statistic and p-value for the most extreme heavy metals

\begin{tabular}{|c|c|c|c|c|c|c|c|c|c|c|}
\hline \multirow{2}{*}{ Fraction } & \multirow{2}{*}{ Unit } & \multicolumn{9}{|c|}{ Heavy metals } \\
\hline & & $\mathrm{Cr}$ & $\mathrm{Mn}$ & Co & $\mathrm{Ni}$ & $\mathrm{Cu}$ & $\mathrm{Zn}$ & As & $\mathrm{Cd}$ & $\mathrm{Pb}$ \\
\hline \multirow{6}{*}{$\begin{array}{c}2000-200 \\
\mu \mathrm{m}\end{array}$} & Mean & 241.4 & 1243.8 & 30.6 & 244.2 & 310.8 & 394.2 & 22.6 & 3.9 & 954.3 \\
\hline & Std.Dev. & 570.1 & 559.1 & 20.5 & 573.8 & 772.9 & 514.2 & 42.6 & 8.6 & 2065.4 \\
\hline & Ex. value & 1651.0 & 1990.0 & 68.6 & 1664.0 & 2223.0 & 1548.5 & 124.0 & 25.0 & 5996.4 \\
\hline & G value & 2.47 & 1.33 & 1.69 & 2.47 & 2.47 & 2.45 & 2.38 & 2.46 & 2.47 \\
\hline & $\mathrm{P}_{2}$ tail of $\mathrm{G}$ & 0.0001 & 0.1679 & 0.2120 & $<0.0001$ & $<0.0001$ & $<0.0001$ & 0.0001 & $<0.0001$ & $<0.0001$ \\
\hline & n. outliers & 1 & 0 & 0 & 1 & 1 & 1 & 2 & 1 & 2 \\
\hline \multirow{6}{*}{$\begin{array}{c}200-63 \\
\mu \mathrm{m}\end{array}$} & Mean & 194.1 & 1193.6 & 32.2 & 285.2 & 413.0 & 492.2 & 24.3 & 5.8 & 1415.5 \\
\hline & Std.Dev. & 406.4 & 414.1 & 30.0 & 652.3 & 1025.4 & 765.2 & 41.7 & 13.2 & 3349.8 \\
\hline & Ex. value & 1197.0 & 732.0 & 171.9 & 1898.0 & 2950.0 & 2295.7 & 117.0 & 38.3 & 9668.9 \\
\hline & G value & 2.47 & 1.11 & 2.45 & 2.47 & 2.47 & 2.36 & 2.22 & 2.47 & 2.46 \\
\hline & $\mathrm{P}_{2}$ tail of $\mathrm{G}$ & $<0.0001$ & 0.2628 & $<0.0001$ & $<0.0001$ & $<0.0001$ & 0.0003 & 0.0025 & $<0.0001$ & $<0.0001$ \\
\hline & n. outliers & 1 & 0 & 1 & 2 & 1 & 1 & 2 & 1 & 3 \\
\hline \multirow{6}{*}{$63-2 \mu \mathrm{m}$} & Mean & 162.1 & 1128.3 & 32.2 & 256.9 & 428.5 & 567.7 & 28.9 & 6.4 & 1609.2 \\
\hline & Std.Dev. & 290.1 & 342.2 & 30.0 & 564.1 & 1052.0 & 925.1 & 49.3 & 15.2 & 3855.6 \\
\hline & Ex. value & 873.0 & 1620.0 & 104.3 & 1651.0 & 3031.0 & 2769.0 & 138.0 & 43.8 & 11108.4 \\
\hline & G value & 2.45 & 1.44 & 2.40 & 2.47 & 2.47 & 2.38 & 2.21 & 2.47 & 2.46 \\
\hline & $\mathrm{P}_{2}$ tail of $\mathrm{G}$ & $<0.0001$ & 0.1313 & $<0.0001$ & $<0.0001$ & $<0.0001$ & 0.0001 & 0.0027 & $<0.0001$ & $<0.0001$ \\
\hline & n. outliers & 1 & 0 & 1 & 2 & 1 & 1 & 4 & 1 & 2 \\
\hline \multirow{6}{*}{$<2 \mu \mathrm{m}$} & Mean & 225.4 & 1337.5 & 46.4 & 380.7 & 682.0 & 721.5 & 48.9 & 7.7 & 2012.6 \\
\hline & Std.Dev. & 349.0 & 369.5 & 56.7 & 825.7 & 1711.0 & 1155.3 & 79.8 & 19.2 & 4966.1 \\
\hline & Ex. value & 1060.0 & 816.0 & 185.6 & 2417.0 & 4916.0 & 3512.4 & 232.0 & 55.2 & 14282.8 \\
\hline & G value & 2.39 & 1.52 & 2.46 & 2.47 & 2.47 & 2.42 & 2.29 & 2.47 & 2.47 \\
\hline & $P_{2}$ tail of $G$ & $<0.0001$ & 0.1054 & $<0.0001$ & $<0.0001$ & $<0.0001$ & $<0.0001$ & 0.0009 & $<0.0001$ & $<0.0001$ \\
\hline & n. outliers & 2 & 0 & 1 & 2 & 1 & 1 & 1 & 1 & 1 \\
\hline
\end{tabular}

Note: the value of 2.1266 is the $G_{\text {critical value }}(0.05)$ based on the numbers of samples (8). The test has been repeated several times till the identifications of outlier number. The $G$ value was calculated from the most extreme value of all selected locations.

In most of the soils the concentration of heavy metals and metalloids increased as soil particle size decreased (Table 4). Correlations of obtained concentrations versus the log means of the particle size fractions indicate the presence of other phases than sorbed on particle surfaces; in other words, the presence of unweathered allochthonous minerals. This is the case in Arzwaldgraben for $\mathrm{Cd}, \mathrm{Co}, \mathrm{Mn}$, and $\mathrm{Pb}$, in case of Hinterlobming for some $\mathrm{Pb}$, in case of Kraubath for $\mathrm{Cd}$, in case of Johnsbach for $\mathrm{Cd}, \mathrm{Co}, \mathrm{Mn}, \mathrm{Pb}$ and $\mathrm{Zn}$ in case of Pilgersdorf for $\mathrm{Cr}$ and some $\mathrm{As}, \mathrm{Cd}, \mathrm{Co}, \mathrm{Mn}, \mathrm{Ni}$ and $\mathrm{Pb}$, in case of Rabenstein for almost all trace elements investigated (except $\mathrm{Cu}$ ) and in case of Zeltweg just for some $\mathrm{Mn}$ and $\mathrm{Cd}$. This trend was also found by many researchers (Sager and Belocky, 1991; Chopin and Alloway, 2007; Liu et al., 2018). To the contrary, the control soil in the industrial area of Arnoldstein had received their metal loads exclusively from effluents or from weathered phases, where the metal concentrations were significantly higher in the finer soil particles (Figure 2). The general increase of metal concentration with decreasing grain size is most pronounced for As and less pronounced for $\mathrm{Cu}$ and $\mathrm{Cd}$ in our study. However, differences between the soil samples are more significant than differences between the elements.

It is suggested that heavy metals and metalloids, which are enriched in the finer fractions, entered the soil via aqueous solutions and precipitated as fine-grained minerals in the pores, or were adsorbed at the mineral surfaces. The samples from Johnsbach and Arzwaldgraben are gley soils, i.e. groundwater influence played an important role in pedogenesis. However, as only the upper $25 \mathrm{~cm}$ of these soils were used for the experiments, it is suggested that the metal-bearing aqueous solutions infiltrated the soil rather from the surface than from the groundwater. Interestingly the two gley samples are the only ones, in which Mn concentrations were highest in the coarsest fraction. $\mathrm{Mn}$ is a redox-sensitive element, of which the oxidized state Mn (IV) is less mobile than its reduced state Mn (II). Gley-reducing conditions in the lower $\mathrm{B}_{\mathrm{r}}$ horizon mobilize $\mathrm{Mn}$ and transport it into the upper oxidizing $\mathrm{B}_{\mathrm{o}}$ horizon, where it gets oxidized and precipitates. However, if this process would take place in topsoil samples, Mn should be enriched in finer particle size fractions. 
Table 4. Metal total concentrations $\left(\mathrm{mg} \mathrm{kg}^{-1}\right)$ in different particle sizes and the correlation of obtained concentrations versus the log means of particle sizes

\begin{tabular}{|c|c|c|c|c|c|c|c|c|c|}
\hline \multirow[t]{2}{*}{ Location } & \multicolumn{9}{|c|}{ Heavy metals concentration $\left(\mathrm{mg} \mathrm{kg}^{-1}\right)$} \\
\hline & $\mathrm{Cr}$ & $\mathrm{Mn}$ & Co & $\mathrm{Ni}$ & $\mathrm{Cu}$ & $\mathrm{Zn}$ & As & $\mathrm{Cd}$ & $\mathrm{Pb}$ \\
\hline Arz 2000-200 $\mu \mathrm{m}$ & 78.3 & 1719 & 32.4 & 59.2 & 40.3 & 618.5 & $<0.3$ & 3.20 & 1020.0 \\
\hline Arz 200-63 $\mu \mathrm{m}$ & 78.5 & 1373 & 28.3 & 65.9 & 50.1 & 679.2 & $<0.3$ & 3.31 & 937.2 \\
\hline Arz $63-2 \mu \mathrm{m}$ & 97.0 & 1607 & 34.5 & 72.1 & 65.0 & 777.7 & $<0.3$ & 3.75 & 1103.7 \\
\hline $\operatorname{Arz}<2 \mu \mathrm{m}$ & 126.8 & 1092 & 29.6 & 76.3 & 60.6 & 804.8 & $<0.3$ & 2.38 & 878.4 \\
\hline correlation coeff. (r) & -0.96 & 0.85 & 0.23 & -0.96 & -0.79 & -0.93 & - & 0.60 & 0.49 \\
\hline Hin 2000-200 $\mu \mathrm{m}$ & 63.4 & 657 & 12.8 & 62.2 & 19.4 & 50.7 & 0.3 & 0.03 & 13.9 \\
\hline Hin $200-63 \mu \mathrm{m}$ & 102.1 & 732 & 16.5 & 117.4 & 22.5 & 64.8 & 1.2 & 0.13 & 9.3 \\
\hline Hin $63-2 \mu \mathrm{m}$ & 132.2 & 1017 & 19.2 & 126.7 & 29.5 & 90.2 & 1.3 & 0.14 & 12.5 \\
\hline $\operatorname{Hin}<2 \mu \mathrm{m}$ & 304.5 & 1790 & 37.5 & 256.3 & 67.2 & 187.8 & 12.5 & 0.42 & 30.6 \\
\hline correlation coeff. (r) & -0.97 & -0.96 & -0.96 & -0.98 & $'-0.94$ & -0.96 & -0.90 & -0.97 & -0.81 \\
\hline Joh 2000-200 $\mu \mathrm{m}$ & $<0.4$ & 1990 & 58.2 & 28.7 & 2223 & 349 & 124 & 0.99 & 169 \\
\hline Joh $200-63 \mu \mathrm{m}$ & 1.2 & 1194 & 30.8 & 27.8 & 2950 & 107 & 117 & 1.54 & 130 \\
\hline Joh $63-2 \mu \mathrm{m}$ & 2.0 & 689 & 26.5 & 32.9 & 3031 & 110 & 138 & 0.46 & 109 \\
\hline Joh $<2 \mu \mathrm{m}$ & 8.5 & 816 & 23.8 & 43.1 & 4916 & 140 & 232 & $<0.05$ & 163 \\
\hline correlation coeff. (r) & -0.94 & 0.81 & 0.82 & -0.93 & -0.97 & 0.63 & -0.90 & 0.77 & 0.02 \\
\hline Kra 2000-200 $\mu \mathrm{m}$ & 20.4 & 705 & 7.6 & 18.5 & 11.5 & 43.7 & $<0.3$ & 0.14 & 17.0 \\
\hline Kra 200-63 $\mu \mathrm{m}$ & 39.4 & 907 & 11.3 & 37.6 & 29.8 & 107 & $<0.3$ & 0.63 & 25.3 \\
\hline $\operatorname{Kra} 63-2 \mu \mathrm{m}$ & 36.4 & 801 & 10.9 & 32.7 & 24.8 & 106 & $<0.3$ & 0.19 & 22.5 \\
\hline $\mathrm{Kra}<2 \mu \mathrm{m}$ & 65.3 & 1249 & 18.2 & 53.4 & 45.3 & 205 & 0.7 & 0.35 & 42.5 \\
\hline correlation coeff. (r) & -0.97 & -0.91 & -0.97 & -0.94 & -0.94 & -0.98 & -0.87 & -0.16 & -0.94 \\
\hline Rab 2000-200 $\mu \mathrm{m}$ & 43.1 & 1951 & 34.8 & 51.4 & 56.6 & 422 & 6.2 & 1.67 & 339 \\
\hline Rab 200-63 $\mu \mathrm{m}$ & 36.3 & 1966 & 33.8 & 52.1 & 65.2 & 512 & 6.4 & 2.15 & 422 \\
\hline Rab 63-2 $\mu \mathrm{m}$ & 35.1 & 1620 & 25.9 & 46.9 & 59.5 & 492 & 4.4 & 2.04 & 359 \\
\hline $\mathrm{Rab}<2 \mu \mathrm{m}$ & 49.1 & 1495 & 23.8 & 56.6 & 67.9 & 602 & 5.7 & 1.63 & 390 \\
\hline correlation coeff. (r) & -0.47 & 0.90 & 0.91 & -0.50 & -0.78 & -0.95 & 0.35 & 0.11 & -0.37 \\
\hline Zel 2000-200 $\mu \mathrm{m}$ & 46.5 & 1104 & 16.7 & 35.8 & 37.4 & 88.2 & 12.0 & 0.36 & 76.2 \\
\hline Zel 200-63 $\mu \mathrm{m}$ & 60.1 & 969 & 18.3 & 46.0 & 43.2 & 113.7 & 12.9 & 0.24 & 119.0 \\
\hline Zel 63-2 $\mu \mathrm{m}$ & 77.6 & 1150 & 20.6 & 54.2 & 56.3 & 140.0 & 21.6 & 0.45 & 149.6 \\
\hline $\mathrm{Zel}<2 \mu \mathrm{m}$ & 127.8 & 1727 & 34.3 & 96.3 & 99.7 & 238.6 & 54.0 & 0.93 & 298.8 \\
\hline correlation coeff. (r) & -0.99 & -0.86 & -0.95 & -0.97 & -0.96 & -0.98 & -0.94 & -0.88 & -0.98 \\
\hline$A(C) 2000-200 \mu \mathrm{m}$ & 28.4 & 786 & 14.0 & 33.9 & 65.2 & 1548.5 & 35.2 & 25.00 & 5996.4 \\
\hline$A(C) 200-63 \mu \mathrm{m}$ & 38.3 & 868 & 14.5 & 36.5 & 100.2 & 2295.7 & 54.8 & 38.31 & 9668.9 \\
\hline$A(C) 63-2 \mu \mathrm{m}$ & 43.8 & 950 & 15.3 & 39.0 & 121.6 & 2769.0 & 64.4 & 43.83 & 11108.4 \\
\hline $\mathrm{A}(\mathrm{C})<2 \mu \mathrm{m}$ & 61.2 & 1085 & 18.2 & 46.7 & 141.2 & 3512.4 & 82.2 & 55.21 & 14282.8 \\
\hline correlation coeff. (r) & -0.99 & -0.99 & -0.97 & -0.99 & -0.96 & -0.99 & -0.99 & -0.98 & -0.98 \\
\hline$P(C) 2000-200 \mu \mathrm{m}$ & 1651 & 1039 & 68.6 & 1664 & 32.8 & 33.0 & 2.3 & 0.14 & 2.8 \\
\hline$P(C) 200-63 \mu \mathrm{m}$ & 1197 & 1540 & 171.9 & 1898 & 42.6 & 58.0 & 1.2 & 0.17 & 12.4 \\
\hline$P(C) 63-2 \mu \mathrm{m}$ & 873 & 1192 & 104.3 & 1651 & 40.3 & 56.5 & 0.9 & $<0.05$ & 9.3 \\
\hline $\mathrm{P}(\mathrm{C})<2 \mu \mathrm{m}$ & 1060 & 1766 & 185.6 & 2417 & 57.7 & 81.4 & 3.7 & 0.30 & 14.8 \\
\hline correlation coeff. (r) & 0.71 & -0.80 & -0.72 & -0.84 & -0.96 & -0.97 & -0.53 & -0.60 & -0.84 \\
\hline
\end{tabular}

Some elements in certain soil samples, however, are enriched in the coarse fractions. For example, in the soil of Pilgersdorf, where we had assumed geogenic enrichments, this is the case for Cr. This soil had developed upon serpentinite, a rock type in which $\mathrm{Cr}$ is in most cases present as chromite (Vollprecht et al., 2019), which is highly resistant against chemical and physical weathering due to its low solubility and high hardness, respectively. Consequently, chromite grains survive during pedogenesis and remain present in the coarse fraction of the soil. $\mathrm{Ni}$ is enriched in ultramafic rocks and soils in olivine as well as in serpentine minerals (lizardite, antogorite, chrysotile) (Sager, 2019).

$\mathrm{Mn}$ and Co contents dominate the sand fractions of the soil at Johnsbach, and to a lesser extent, at Arzwaldgraben and Rabenstein. All these soils have developed on substrates which contain sulfide ore deposits. Weathering of sulfide ores may lead to the precipitation of secondary minerals, like Co sulfates or arsenates. Enrichment of Co in the coarse fraction, however, suggests that a significant proportion of Co is still present in weathering relicts, e.g. as substitutes in silicates or oxides. The same might be valid for $\mathrm{Zn}$ at Johnsbach and for As at Rabenstein.

To the contrary, emissions from modern steel works include spherulic micro-particles of iron oxides, fly ash particles from the combustion of fossil fuels, whereas irregular and angular particles of Fe-oxides are associated with abrasions of combustion cylinders, pads and disc brakes of vehicles. Whereas spherical 
particles originate from the smelting and flue gas cleaning processes, angular particles have either geogenic origins or they are windblown from waste disposal sites. Sulphides from ores and mine tailings often exhibit weathering rims in contrast to smelter-derived high-temperature sulphides. Mixed Fe-oxides are weathering features (Ettler and Johan, 2014).
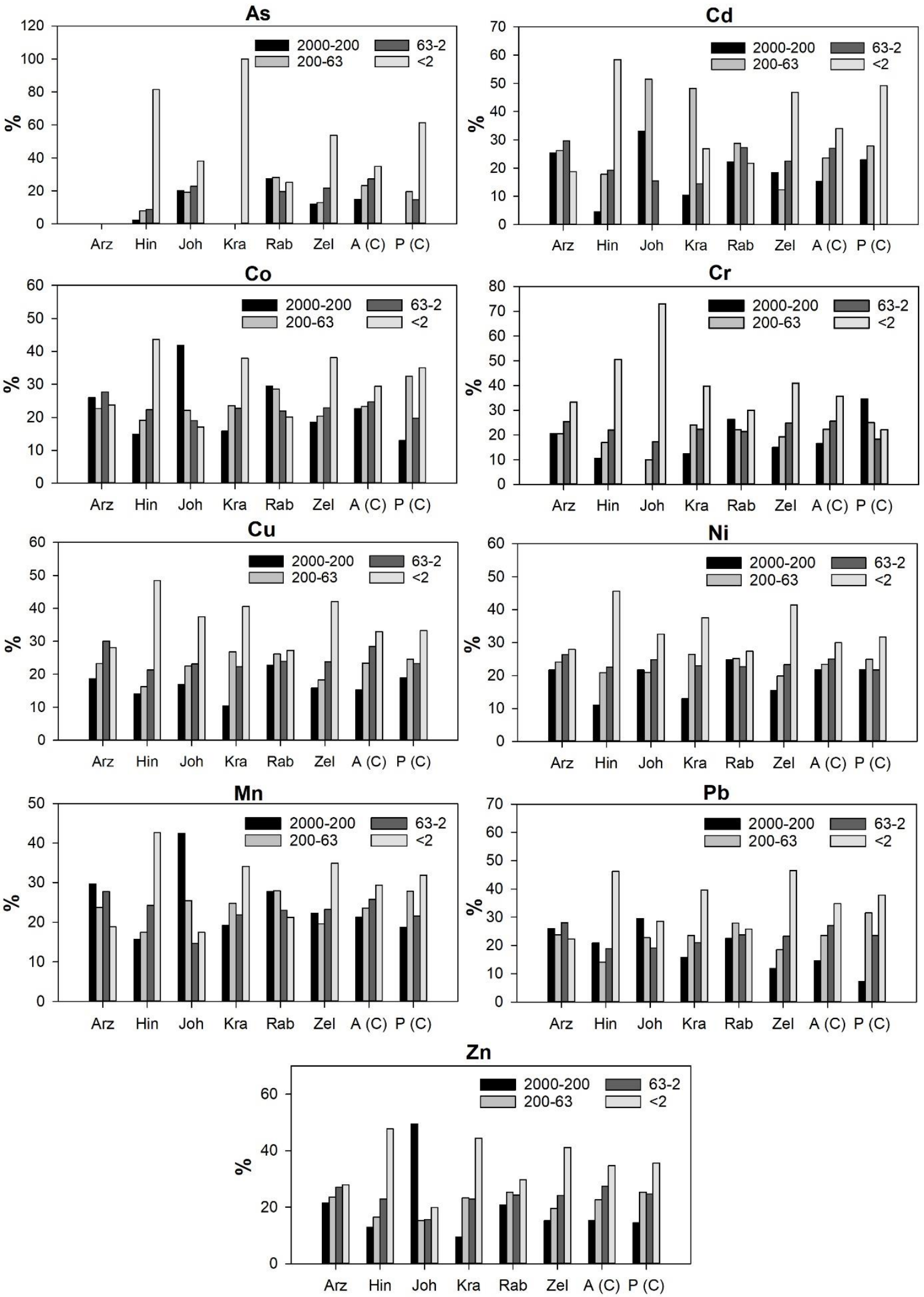

Figure 2. Distribution of heavy metals and metalloids in different particle grain sizes of selected soils

Grain-size fractionation of calcareous fluvisols by shaking in water led to lower percentage of the clay fraction versus ultrasonic or chemical pretreatment with dilute $\mathrm{HCl}$ (decarbonisation) and $\mathrm{H}_{2} \mathrm{O}_{2}$ (oxidation of organics). Ultrasonic vibrations broke the associations of fine minerals with organic matter down to $0.2-2.0$ 
$\mu \mathrm{m}$ size and transferred $\mathrm{C}$ and $\mathrm{N}$ from coarser to the clay fraction. The phyllosilicates were concentrated in the clay fraction, and the carbonates in the silt and sand, but were broken by ultrasonic treatment. After densimetric fractionation with tetrabromoethane-polyvinylpyrolidone-ethanol, $\mathrm{Cd}$ from polluted samples dissolved at about 10\%, but other metals negligibly (Ducaroir et al., 1990).

\section{Extracts with $\mathrm{CaCl}_{2}$}

Though the water-soluble fractions had been lost during the sample preparation step, extraction with $\mathrm{CaCl}_{2}-$ solution might give an indication of exchangeable respectively weathered phases (Table 5). The proportion of exchangeable over aqua regia extractable fractions did not depend on the particle size fractions. Exchangeable Mn could be an indicator for carbonaceous- bound $\mathrm{Mn}$, because reaction of $\mathrm{MnCO}_{3}$ with $\mathrm{CaCl}_{2}$ to yield soluble $\mathrm{MnCl}_{2}$ and $\mathrm{CaCO}_{3}$ seems feasible. In $0.5 \mathrm{M} \mathrm{MgCl}_{2}$-extract $1: 10$, which is comparable to the $\mathrm{CaCl}_{2}$-extract data presented in, about $12 \%$ of total $\mathrm{Mn}$ was found exchangeable in a calcareous cambisol, like in the current sample from Johnsbach. In a podsol, an acid cambisol, and a calcareous leptosol profile, about $5 \%$ of $\mathrm{Mn}$ were exchangeable, like current samples from Arzwaldgraben, Hinterlobming and Arnoldstein (Sager and Mutsch, 2007). Precipitation of Fe and Mn from oxygenated water at circumneutral pH is known to produce ferric oxide plus manganous carbonate (Mettler et al., 2001). Amounts at $1 \%$ of exchangeable Mn or less indicate non-weathered Mn-containing phases. Similarly, about 3\% of exchangeable Zn at Johnsbach and 3\% of exchangeable $\mathrm{Cd}$ in the Arnoldstein-samples indicate rather high weathering of $\mathrm{Zn} / \mathrm{Cd}$ minerals or additional $\mathrm{Zn}$ respectively $\mathrm{Cd}$ input, because exchangeable $\mathrm{Zn}$ in non-contaminated forest soils is expectable at $1 \%$, and in podsoils at $2 \%$ (Sager and Mutsch, 2007). In case of $\mathrm{Cu}$, exchangeable $<0.5-1 \%$ are typical for ambient levels. At non-contaminated sites, exchangeable $\mathrm{Pb}, \mathrm{Cr}, \mathrm{Ni}$, and $\mathrm{Co}$ were negligible, but at Hinterlobming and Johnsbach, some \% of $\mathrm{Ni}$ and Co were detected. At Pilgersdorf, exchangeables were negligible, except for $\mathrm{Pb}$. Thus, the proportion of exchangeables indicates the weathering status of the given sample.

Table 5. Metals soluble in $\mathrm{CaCl}_{2}$ extract of sand (2000-63) and silt-clay $(<63)$ fractions

\begin{tabular}{|c|c|c|c|c|c|c|c|c|}
\hline \multirow[t]{2}{*}{ Location } & \multicolumn{8}{|c|}{ Heavy metals concentration $\left(\mathrm{mg} \mathrm{kg}^{-1}\right)$} \\
\hline & $\mathrm{Cr}$ & $\mathrm{Mn}$ & Co & $\mathrm{Ni}$ & $\mathrm{Cu}$ & $\mathrm{Zn}$ & $\mathrm{Cd}$ & $\mathrm{Pb}$ \\
\hline Arz 2000-63 $\mu \mathrm{m}$ & 0.00 & 77.92 & 0.00 & 0.13 & 0.17 & 0.53 & 0.00 & 0.07 \\
\hline Arz $<63 \mu \mathrm{m}$ & 0.00 & 84.93 & 0.00 & 0.10 & 0.20 & 0.51 & 0.00 & 0.07 \\
\hline Hin 2000-63 $\mu \mathrm{m}$ & 0.00 & 64.23 & 0.42 & 1.51 & 0.00 & 0.45 & 0.00 & 0.05 \\
\hline $\operatorname{Hin}<63 \mu \mathrm{m}$ & 0.00 & 46.82 & 0.39 & 2.15 & 0.04 & 0.73 & 0.00 & 0.05 \\
\hline Joh 2000-63 $\mu \mathrm{m}$ & 0.00 & 130.41 & 1.15 & 0.73 & 16.28 & 3.03 & 0.00 & 0.03 \\
\hline Joh $<63 \mu \mathrm{m}$ & 0.00 & 78.21 & 0.51 & 0.86 & 13.47 & 3.24 & 0.00 & 0.02 \\
\hline Kra 2000-63 $\mu \mathrm{m}$ & 0.00 & 9.24 & 0.00 & 0.05 & 0.00 & 0.11 & 0.00 & 0.03 \\
\hline Kra $<63 \mu \mathrm{m}$ & 0.00 & 10.15 & 0.00 & 0.06 & 0.00 & 0.12 & 0.00 & 0.02 \\
\hline Rab 2000-63 $\mu \mathrm{m}$ & 0.00 & 40.99 & 0.00 & 0.21 & 0.00 & 2.30 & 0.00 & 0.00 \\
\hline $\mathrm{Rab}<63 \mu \mathrm{m}$ & 0.00 & 45.29 & 0.03 & 0.25 & 0.07 & 3.64 & 0.00 & 0.06 \\
\hline Zel 2000-63 $\mu \mathrm{m}$ & 0.00 & 8.19 & 0.00 & 0.05 & 0.00 & 0.11 & 0.00 & 0.05 \\
\hline $\mathrm{Zel}<63 \mu \mathrm{m}$ & 0.00 & 11.84 & 0.00 & 0.06 & 0.04 & 0.12 & 0.00 & 0.04 \\
\hline $\mathrm{A}(\mathrm{C}) 2000-63 \mu \mathrm{m}$ & 0.00 & 55.83 & 0.00 & 0.04 & 0.34 & 3.08 & 1.22 & 5.81 \\
\hline $\mathrm{A}(\mathrm{C})<63 \mu \mathrm{m}$ & 0.00 & 54.95 & 0.00 & 0.07 & 0.77 & 2.99 & 1.16 & 7.87 \\
\hline $\mathrm{P}(\mathrm{C}) 2000-63 \mu \mathrm{m}$ & 0.17 & 1.71 & 0.00 & 1.78 & 0.00 & 0.12 & 0.00 & 0.08 \\
\hline $\mathrm{P}(\mathrm{C})<63 \mu \mathrm{m}$ & 0.10 & 1.44 & 0.00 & 1.98 & 0.00 & 0.12 & 0.00 & 0.06 \\
\hline
\end{tabular}

\section{Conclusion}

This study demonstrates that the heavy metal distribution between different particle size fractions of Austrian soils is a tool to identify the sources of the pollution. Four out of seven investigated soil samples show an increase in heavy metal concentration with increasing particle size suggesting their incorporation into primary mineral phases which survived weathering. The other three samples show a decrease in heavy metal concentration with increasing particle size which can be explained by their presence as fine-grained secondary minerals which have precipitated from heavy metal bearing aqueous soil solutions. However, by distinguishing between anthropogenic and geogenic pollution two other facts must be taken into account: Firstly, anthropogenic pollution can be due to the disposal of heavy metal containing solid waste as well as from the discharge of heavy metal bearing waste water, yielding to an enrichment of heavy metals in the coarse and fine fraction, respectively. Secondly, also geogenic pollution can be due to the enrichment of heavy metals in secondary minerals, e.g. of Ni during a laterization process, i.e. in the fine fractions, but also due to the presence of heavy metals in weathering relicts such as chromite, $\mathrm{FeCr}_{2} \mathrm{O}_{4}$. 


\section{References}

Adriano, D. C., 1986. Trace elements in the terrestrial environment. Springer-Verlag, Berlin. 533p.

Ajmone-Marsan, F., Biasioli, M., Kralj, T., Grčman, H., Davidson, C.M., Hursthouse, A.S., Madrid, L., Rodrigues, S., 2008. Metals in particle-size fractions of the soils of five European cities. Environmental Pollution 152(1): 73-81.

Bradl, H.B., 2004. Adsorption of heavy metal ions on soils and soils constituents. Journal of Colloid and Interface Science 277(1): 1-18.

Chao, T.T., Theobald, P.K., 1976. The significance of secondary iron and manganese oxides in geochemical exploration. Economic Geology 71(8): 1560-1569.

Chopin, E.I.B., Alloway, B.J., 2007. Distribution and mobility of trace elements in soils and vegetation around the mining and smelting areas of Tharsis, Ríotinto and Huelva, Iberian Pyrite Belt, SW Spain. Water Air and Soil Pollution 182(1-4): 245-261.

Chung, E.H., Lee, J.S., Chon, H.T., Sager, M., 2005. Environmental contamination and bioaccessibility of arsenic and metals around the Dongjeong $\mathrm{Au}-\mathrm{Ag}-\mathrm{Cu}$ mine, Korea. Geochemistry: Exploration, Environment, Analysis 5(1): 6974.

Ducaroir, J., Cambier, Ph., Leydecker, J.P., Prost, R., 1990. Application of soil fractionation methods to the study of the distribution of pollutant metals. Zeitschrift für Pflanzenernährung und Bodenkunde 153(5): 349-358.

Ettler, V.,Johan, Z., 2014. 12 years of leaching of contaminants from Pb smelter slags. Applied Geochemistry 40: 97-103.

Gong, C., Ma, L., Cheng, H., Liu, Y., Xu, D., Li, B., Liu, F., Ren, Y., Liu, Z., Zhao, C., Yang, K., Nie, H., Lang, C., 2014. Characterization of the particle size fractions associated heavy metals in tropical arable soils from Hainan Island, China. Journal of Geochemical Exploration 139: 109-114.

Jelecevic, A., Horn, D., Eigner, H., Sager, M., Liebhard, P., Moder, K., Vollprecht, D., 2019. Kinetics of lead release from soils at historic mining and smelting sites, determined by a modified electro-ultrafiltration. Plant, Soil and Environment 65(6): 298-306.

Jelecevic, A., Wellacher, M., Sager, M., Liebhard, P., 2018. Schwermetalle in Böden von ausgewählten Standorten in der Steiermark. Wasser und Abfall 5: 25-31 [In German].

Kuffner, M., Puschenreiter, M., Wieshammer, G., Gorfer M., Sessitsch A., 2008. Rhizosphere bacteria affect growth and metal uptake of heavy metal accumulating willows. Plant and Soil 304: 35-44.

Lim, H.S., Lee, J.S., Chon, H.T., Sager, M., 2008. Heavy metal contamination and health risk assessment in the vicinity of the abandoned Songcheon Au-Ag mine in Korea. Journal of Geochemical Exploration 96(2-3): 223-230.

Liu, G., Wang, J., Liu, X., Liu, X., Li, X., Ren, Y., Wang, J., Dong, L., 2018. Partitioning and geochemical fractions of heavy metals from geogenic and anthropogenic sources in various soil particle size fractions. Geoderma 312: 104-113.

Mandzhieva, S., Minkina, T., Pinskiy, D., Bauer, T., Sushkova, S., 2014. The role of soil's particle-size fractions in the adsorption of heavy metals. Eurasian Journal of Soil Science 3(3): 197-205.

Mattigod, S.V., Page, A.L., Thornton, I., 1986. Identification of some trace metal minerals in a mine-waste contaminated soil. Soil Science Society of America Journal 50(1): 254-258.

Mettler, S., Abdelmoula, M., Hoehn, E., Schoenenberger, R., Weidler, P., von Gunten, U., 2001. Characterization of iron and manganese precipitates from an in situ ground water treatment plant. Groundwater 39(6): 921-930.

Pandey, P.K., Sharma, R., Roy, M., Pandey M., 2007. Toxic mine drainage from Asia's biggest copper mine at Malanjkhand, India. Environmental Geochemistry and Health 29: 237-248.

Sager, M., 2019. Nickel - A trace element hardly considered. International Journal of Horticulture, Agriculture and Food Science (IJHAF) 3(2): 75-90.

Sager, M., Belocky, R., 1990. Zur Geochemie, Mineralogie und Sedimentologie von Feinsedimenten aus dem Donaustauraum Altenwörth, Niederösterreich. Mitteilungen der Österreichischen Geographischen Gesellschaft 83: 267-281 [In German].

Sager, M., Mutsch, F., 2007. Sequential leaching to detect mobility changes of main and trace elements in forest soil profiles. Mitteilungen der Österreichischen Bodenkundlichen Gesellschaft 74: 87-110.

Stemmer, M., Gerzabek, M. H., Kandeler, E., 1998. Organic matter and enzyme activity in particle-size fractions of soils obtained after low-energy sonication. Soil Biology and Biochemistry 30 (1): 9-17.

Tuhý, M., Hrstka, T., Ettler, V., 2020. Automated mineralogy for quantification and partitioning of metal(loid)s in particulates from mining/smelting-polluted soils. Environmental Pollution 266: 115118.

Vollprecht, D., Berger, M., Altenburger-Junker, I., Neuhold, S.F., Sedlazeck, K.P., Aldrian, A., Dijkstra, J.J., van Zomeren, A., Raith, J.G., 2019. Mineralogy and leachability of natural rocks-A comparison to electric arc furnace slags. Minerals 9(8): 501.

Wenzel, W.W., Bunkowski, M., Puschenreiter, M., Horak, O., 2003. Rhizosphere characteristics of indigenously growing nickel hyperaccumulator and excluder plants on serpentine soil. Environmental Pollution 123 (1):131-138.

Yao, Q., Wang, X., Jian, H., Chen, H., Yu, Z., 2015. Characterization of the particle size fraction associated with heavy metals in suspended sediments of the Yellow River. International Journal of Environmental Research and Public Health 12(6): 6725-6744.

Zhang, H., Luo, Y., Makino, T., Wu, L., Nanzyo, M., 2013. The heavy metal partition in size-fractions of the fine particles in agricultural soils contaminated by waste water and smelter dust. Journal of Hazardous Materials 248-249: 303312. 